\title{
The Relationship between Corporate Music and Corporate Image Building
}

\author{
Yong Zhou \\ Art Institute, Yulin University, Yulin, Shaanxi, China \\ 317950860@qq.com
}

\begin{abstract}
Keywords: Corporate music; Corporate image building; Corporate culture; Enterprise development
\end{abstract}
\begin{abstract}
With the domestic political, economic and cultural development, how to enhance corporate image and improve the competitiveness of enterprises has become a focus of the current development of enterprises. Enterprise music is not only an important part of corporate culture, but also an important carrier of enterprise publicity and shaping a good social image. How to treat the relationship between the two, to understand how to use music to promote the art of shaping the corporate image, this is not only reflected the social function of music, art truly to serve the society, is an important part of music educators should study, but also corporate executives should think about the problem. In the following, the author studies and analyzes the relationship between music and corporate image.
\end{abstract}

\section{Introduction}

Music is the product of social development, is a component of social consciousness, but also reflects the important reference of social development. There is no doubt that music, like other forms of art, has social functions. The social function of music refers to the function of music to the development of society. As early as in the spring and Autumn period, representatives of the pre Qin Confucian thinking of music works "music", "music has been proposed and Zhengtong" thought, and expounds the social function of music. [1,2,3] The emergence of enterprises is also the product of social development and the pillar of social development. The development of enterprises has a direct impact on the overall development of society, politics and culture. Enterprise music is the product of the combination of music and enterprise, representing the development and progress of enterprises. Moreover, enterprise music plays a very important role in enterprise product publicity and corporate image building. At the same time, the economic benefits of enterprises have improved, and the leaders of enterprises have paid more attention to the development of the enterprise economy. At the same time, they will play a great role in promoting the development of enterprise culture, especially the music of enterprises. [4,5,6,7]

\section{The Function and Characteristics of Enterprise Music}

Enterprise music is produced in the process of enterprise development a to meet the requirements of the enterprise, the special form of music to some enterprise development purposes, in other words, not all music is suitable for the enterprise, and can be used for enterprise development of music can be called music business. The art of music special social function of the development of the law of art and music, music today, enterprises not only become an important part of corporate culture, is the symbol of enterprise image, enterprise spirit of the whole. For a successful enterprise, not only because it can provide for the vast number of consumers, good quality products, more important is the enterprise contains excellent enterprise culture and enterprise management, and enterprise music is an effective way of enterprise publicity and the cultural connotation of the concept of enterprise management. There is no doubt that enterprises have a good image and can increase their potential market competitiveness. [8,9,10]Such as Haier, Tsingtao Brewery and other enterprises created by the enterprise music has long been known, although these enterprises in the creation of enterprise music has invested, but also to the enterprise has brought a fruitful report. Again, Yuan chemical, 
Shenhua Group and other well-known enterprises and enterprise songs, the lyrics are closely related, embodies the characteristics of enterprises, reflect the development and pursuit of the spirit of enterprise, not only increase the internal cohesion of enterprise employees. Because of this, more and more enterprises begin to pay attention to the construction of enterprise music culture.

Enterprise Music can Enhance the Internal Cohesion of Enterprises. This paper represents the ancient Chinese Confucian writings "music", "music system, etiquette difference between" music features "and", the purpose is "and the same", through the music of this art form, can combine different human emotions. The pre Qin period of Xunzi in his treatise "music theory" pointed out that "music can make people in a unified Avenue, to cope with any social change", in other words, music can make people energetic and solidarity between people and enhance the cohesiveness. Enterprise music is the spirit of enterprise, enterprise management concept and the spirit of enterprise workers concentrated into a specific form of music, so that the soul of enterprise workers have been purified, and produce a common ideal. Because of the special social function of music, more and more enterprises pay more attention to the construction of enterprise music.

Enterprise Music can adjust the Mental Status of Workers and Promote the Potential Creativity of Enterprises. From ancient times to the present, many scholars have discussed the interaction between music and human beings. There are many such records in ancient China, such as "Jin Shu - Le Chi" about "is to hear the sound, the gentle palace and broad; Wen Shang, the party and a good sense of smell; the angle of sound, make someone hidden love; Wen Zhi tone, make people have heard the music and work; feather sound, make the person being polite and respectful". This passage is an ancient concern about the influence of music on human character and behavior. Another example of China's song writer Ou Yangxiu in "the preface" about Yang sent "to try to have the worry of the disease, and can cure back at. Then the piano in his friend Sun Daozi, the house number of sound, long and happy, I do not know the disease in the body also confirmed the "learning instrumental music can make the negative mentality weakening sentiment on the treatment of depression, the restoration of physical and mental health has a positive effect. In the contemporary era, many music researchers have studied the relationship between music and human beings from different levels and perspectives, and even some studies have shown interdisciplinary and multi-disciplinary studies.

Enterprise music is an important component of corporate culture, corporate songs is an important form of externalization of corporate music, is an important connotation of enterprise spirit, is a vivid expression of the concept of enterprise management. Because of the special artistic charm of music itself, it has become the most appealing and appealing art form. In March for the enterprise song structure, orchestration and other musical instruments, allowing employees to experience the whole song of the principle of beauty at the same time, the connotation of a deeper understanding of the spirit of enterprise. Business enterprise of music as an important carrier of the image, not only the above points, the more important is the enterprise music can stimulate staff's cohesion, centripetal force, can arouse the enthusiasm of the staff, enhance the market competitiveness of the enterprise potential. From another point of view, enterprise music can beautify the working environment of enterprise workers, adjust the work mood of workers, and promote the spiritual outlook of enterprise workers greatly. On the contrary, the spirit of enterprise workers reflects the overall spirit of enterprises, enterprises through the promotion of the spirit of workers, so that more people understand the enterprise, thereby promoting the image of the enterprise.

\section{The Influence of Corporate Music on Corporate Image}

There is no doubt that corporate music has a certain influence on corporate image building. Corporate image is a comprehensive evaluation of the society. As a rule, a market competitive enterprise includes good corporate image, enterprise productivity and employee creativity, as well as an excellent marketing team. In a sense, corporate image is the comprehensive competitiveness of enterprises. Usually, the comprehensive competitiveness of an enterprise research mainly includes three aspects, namely, image, commodity and sales force, to some extent, corporate image is productivity, appeal and purchasing power. As can be seen from these contents, good corporate 
image is a kind of sustainable purchasing power and brand equity, good corporate image should not only have the corresponding integration, but also can promote the coordination of internal cooperation, promote sustainable and healthy operation of enterprises, promote the enterprise culture spread from the inside to the outside, to promote the interaction between the enterprise and the for consumers, the integration of enterprise communication value and image value and commodity value, to realize the goal of high efficiency.

First, the enterprise music through the enterprise management philosophy and its spiritual culture of organic combination, make it form a unified whole, become enterprise outward display and communication of an important channel. In recent years, with the development of the concept of corporate image, the formation of corporate image has become an effective tool for enterprises to gain competitive advantage. Corporate image building is based on corporate culture, and through effective image shaping carrier to complete the image of the mold. An effective means of enterprise music as a corporate image building, in the construction of strengthening the understanding of enterprise culture and the phenomenon of the artistic conception, understanding one kind of art, change the past, people simply to carry out business judgment by a visual or material value, is a new mode of enterprise image.

Second, enterprise music for TV advertising adds more elements of aesthetics and art, through the integration of music and the exquisite picture, will ever change this boring TV advertising has become a kind of music and art advertising and has a strong visual effect, so that the public in the visual enjoyment at the same time, will gradually accept the enterprise culture the concept and the image in the subconscious. The foundation and soul of enterprise music is the cultural spirit of an enterprise. Through the language form of music, the spread of enterprise culture, spirit and idea can make people have a correct understanding of the enterprise.

In addition to music business advantages, it has certain disadvantages and defects, namely the scope of easy to be limited, and the production and dissemination of the cost of investment is relatively large, relatively more, for some small enterprises is difficult to bear. In this regard, the role of corporate image creation is limited, and in order to create a good corporate image, but also through the cooperation of other relevant channels can be achieved.

\section{Conclusion}

Enterprise music is not only an important part of corporate culture, but also an important carrier of enterprise publicity and shaping a good social image. How to treat the relationship between the two, to understand how to use music to promote the art of shaping the corporate image, this is not only reflected the social function of music, art truly to serve the society, is an important part of music educators should study, but also corporate executives should think about the problem.

\section{References}

[1] On the influence of enterprise spirit on enterprise music creation [J]. Li Xiaolong. Music time and space. 2014 (09). (in Chinese)

[2] Effect of on enterprise Zhan Qinchuan, music television, shaping and spreading of the corporate image [J]. Wu Hao. Market Modernization. 2010 (07). (in Chinese)

[3] Enterprise, music, television, corporate image shaping and dissemination, [J]., Chen Yongzhi. Press. 2009 (05). (in Chinese)

[4] On the influence and integration strategy of new media on brand communication [J]. Li Qingchun. Chinese media science and technology. 2013 (06). (in Chinese)

[5] In the media enterprise interaction from plastic corporate image [J]. Xinya Jiang. Enterprise civilization. 2011 (04). (in Chinese) 
[6] New media brand communication in the application value, problem and solution of [J]. matende. Shandong Social Science 2009 (08). (in Chinese)

[7] The use of Chinese traditional cultural elements in television advertising creativity [J]. Cheng Juan. Contemporary television. 2015 (11). (in Chinese)

[8] The throbbing of the ordinary - Monroe style, [J]., Sun Jing. Short Stories (original edition). 2015 (23). (in Chinese)

[9] Advertising sign value of myth -- the construction of Wuliangye TV ads "energy-saving" the barthian myth Zhou [J].. Journal of Yibin University 2014 (08). (in Chinese)

[10] Internet, corporate culture, law enforcement, exploration and management innovation, [J]., Wang Chengrong. Corporate culture. 2015 (07). (in Chinese) 